\title{
EFEKTIVITAS EKSTRAK DAUN KEMANGI \\ (Ocimum sanctum L) TERHADAP LARVA NYAMUK \\ AEDES AEGYPTI INSTAR IV \\ TAHUN 2018 \\ Novilia Eka Putri ${ }^{1}$, I Wayan Jana ${ }^{2}$
}

\begin{abstract}
One of communicable disease in Indonesia is Dengue Hemorhaggic Fever caused by the dengue virus and transmitted by the mosquito Aedes aegypti. Various efforts have been made to eradicate the vector control is by either biological, physical and chemical.One of them by exploiting the basil leave extract as a chemical organic control. The purpose of this searching was knows analysis effectiveness power kill extract basil leave in Aedes aegypti mosquito larvae. Type of research is a true experimental design. The research was conducted by providing extract basil leave in various concentrations 7\%, 8\%, and 9\% to the container 25 larvae with 48 hours contact,replication measure in two time control and three replication. Kill ability of extract basil leave in this research will be tested by Kruskall wallis with sig 0,04 analysis result has describe that there were determination doses variety against Aedes aegypti larvae mortality. The resume of researching show that at doses $7 \%$ is a dose that is already effective because able to kill half of the number of test or larvae $L D_{50}$, with an average death of 18 individuals with a percentage of death $73 \%$. Suggestions to the public to use organic pesticides for eradication $D B D$.
\end{abstract}

Keyword : Basil leave; Aedes aegypti larvae.

Penyakit menular adalah jenis penyakit yang disebabkan oleh agen penyakit spesifik atau produk beracun yang ditransmisikan dari orang yang terinfeksi, hewan, atau reservoir benda mati ke penjamu yang rentan, melalui tumbuhan atau hewan perantara, vektor, atau lingkungan mati, baik secara langsung maupun tidak langsung (1)

Penyakit yang ditularkan oleh nyamuk merupakan masalah kesehatan masyarakat, baik di perkotaan maupun di pedesaan. Salah satu penyakit menular yang saat ini sedang mewabah adalah Demam Berdarah Dengue (DBD) (2).

Salah satu upaya yang dapat dilakukan untuk mencegah terjadinya penyakit Demam Berdarah Dengue (DBD) adalah melalui pemberantasan sarang nyamuk (PSN). PSN bertujuan untuk pengendalian terhadap vektor pada fase jentik nyamuk Aedes aegypti. Pengendalian vektor dapat dilakukan melalui pengendalian fisik, pengendalian kimiawi, dan pengendalian biologi.

Pengendalian secara kimiawi pada jentik dapat dilakukan dengan menaburkan bubuk larvasida atau abate. PSN dengan cara larvasida merupakan upaya sasaran untuk memberantas larva nyamuk. Perlakuan tersebut diharapkan dapat meningkatkan Angka Bebas Jentik (ABJ) (3)

Hasil penelitian (4) dengan penggunaan daun kemangi (Ocimum sanctum $L$ ) yang dapat bersifat sebagai larvasida pada nyamuk Aedes aegypti. Kandungan daun kemangi yaitu senyawa flavonoid, saponin, daneugenol. Flavonoid berfungsi sebagai racun pernapasan, saponin sebagai racun perut dan racun kontak, serta eugenol yang berperan dalam denaturasi protein sitoplasmik dan nekrosis jaringan (5)

Penelitian ini menggunakan daun kemangi yang diubah menjadi ekstrak untuk membunuh larva Aedes aegypti 
instar IV. Tujuan umum penelitian ini adalah untuk menganalisis efektivitas daya bunuh ekstrak daun kemangi (Ocimum sanctum $L$ ) dalam membunuh larva Aedes aegypti. Tujuan khususnya adalah (1) Untuk mengetahui angka kematian larva nyamuk Aedes aegypti instar IV dengan pemberian ekstrak daun kemangi dengan dosis 7\%. (2) Untuk mengetahui angka kematian larva nyamuk Aedes aegypti instar IV dengan pemberian ekstrak daun kemangi dengan dosis 8\%. (3) Untuk mengetahui angka kematian larva nyamuk Aedes aegypti instar IV dengan pemberian ekstrak daun kemangi dengan dosis $9 \%$. (4) Untuk menganalisis efektivitas kematian larva Aedes aegypti instar IV dengan pemberian ekstrak daun kemangi dosis $7 \%, 8 \%$, dan $9 \%$.

\section{METODE}

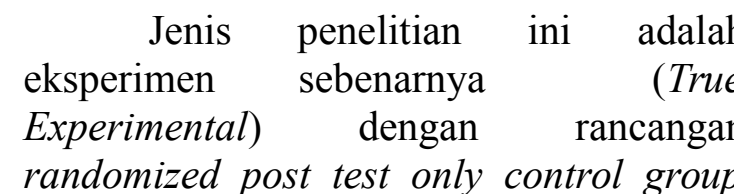
design. Larva nyamuk Aedes aegypti yang digunakan sebagai obyek penelitian diperoleh dari Dinas Kesehatan Propinsi Jawa Timur di Surabaya yaitu berupa telur Nyamuk Aedes aegypti yang siap ditetaskan. Larva yang digunakan adalah larva nyamuk Aedes aegypti instar IV yang telah berumur satu hari. Larva instrar IV merupakan larva yang tubuhnya telah lengkap struktur anatominya dan jelas, tubuh dapat dibagi menjadi bagian kepala (chepal), dada (thorax), dan perut (abdomen) (6) Jumlah telur yang ditetaskan sebanyak 1000 telur, dengan menambahan ekstrak daun kemangi dengan dosis $7 \%, 8 \%$, dan $9 \%$ sebanyak 3 tetes dalam $100 \mathrm{ml}$ air. Analisis dilakukan dengan analisis univariate dan analisis bivariate. Analisis bivariate dilakukan dengan uji Kolmogorov Smirnov, dan Uji Kruskal Wallis kemudian dilanjutkan dengan Uji Mann whitney. kebutuhan 600 ekor larva untuk tiga perlakuan, dua pengulangan pengukuran dan kontrol serta tiga kali replikasi. Jumlah larva uji sebanyak 25 ekor per wadah perlakuan dengan

\section{HASIL DAN PEMBAHASAN \\ Hasil}

1. Suhu dan $\mathrm{pH}$ air

Rata-rata suhu air sebelum dan setelah perlakuan adalah $27^{\circ} \mathrm{C}$ untulk seluruh wadah perlakuan. Sedangkan ratarata $\mathrm{pH}$ air sesudah dan sebelum perlakuan terhadap ketiga dosis tersebut tidak ada perbedaan yaitu 7 .

2. Kematian larva nyamuk Aedes aegypti.

Pengamatan larva nyamuk Aedes aegypti yang mati dilakukan dengan cara menghitung jumlah larva yang mengapung dan tidak bergerak selama 48 jam pada dosis 7\%, 8\%, dan 9\% serta kontrol. Pengamatan berlangsung selama 3 hari untuk melihat perubahan larva yang menjadi pupa (dorman).

Jumlah kematian larva setelah pemberian perlakuan selama 48 jam mulai dari 17 ekor hingga 25 ekor. Dari ketiga dosis yang diberikan serta kontrol terlihat perbedaan jumlah kematian larva. Pada pemberian dosis $7 \%$ kematian terendah terletak pada replikasi I, pengulangan 1 yaitu 17 ekor. Pada pemberian dosis 8\% kematian mulai meningkat dan pada pemberian dosis 9\% kematian sudah mencapai $100 \%$ dari jumlah larva yang diuji.

3. Efektivitas kematian larva

Efektivitas kematian larva dapat dihitung dengan membagi jumlah larva yang mati sesuadah perlakukan dibagi dengan jumlah larva percobaan dikalikan $100 \%$

Hasil perhitungan pada dosis $7 \%$ merupakan dosis yang efektif untuk membunuh larva, karena pada dosis ini kematian larva sudah mencapai $50 \%$ dari jumlah larva yang diuji $\left(\mathrm{LD}_{50}\right)$. Pada dosis $8 \%$ memiliki rata-rata kematian larva

1 Mahasiswa Jurusan Kesehatan Lingkungan Poltekkes Denpasar

2 Dosen Jurusan Kesehatan Lingkungan Poltekkes Denpasar 
sebesar 93 dan pada dosis 9\% memiliki rata-rata sebesar 96. Jika dilihat dari ketiga dosis tersebut, dosis $7 \%$ memiliki kematian yang paling efektif jika dilihat dari pengertian efektivitas yaitu suatu ukuran yang menyatakan seberapa jauh target telah tercapai, dimana makin besar presentase target yang dicapai, makin tinggi efektivitasnya.

\section{Pembahasan}

1. Kematian Larva Pada Dosis 7\%

Kematian larva nyamuk Aedes aegypti yang diberikan dengan dosis 7\% memiliki angka kematian yang cukup tinggi. Pengamatan terhadap kematian larva dilakukan pada kurun waktu 1 jam, 6 jam, 12 jam, dan 48 jam. Rata-rata kematian pada dosis ini sebesar 18 ekor dengan presentase kematian $73 \%$ selama 48 jam perlakuan. Dosis 7\% merupakan dosis efektif dalam penelitian ini karena sudah dapat membunuh larva nyamuk Aedes aegypti setengah dari jumlah larva yang diuji atau sudah mencapai $\mathrm{LD}_{50}$. Hal ini disebabkan karena adanya kandungan metil chavicol dan saponin dalam daun kemangi. Menurut Suparjo (2009), metil chavicol dan saponin merupakan senyawa metabolit sekunder dengan berat molekul tinggi, cara kerjanya meracuni serangga yaitu dengan mencuci lapisan lilin yang melindungi tubuh serangga dan menyebabkan kematian karena serangga akan kehilangan banyak cairan.

2. Kematian Larva Pada Dosis $8 \%$

Kematian larva nyamuk Aedes aegypti yang diberikan dengan dosis $8 \%$ memiliki angka kematian yang tinggi.Pengamatan dilakukan terhadap kematian larva dengan kurun waktu 1 jam, 6 jam, 12 jam, dan 48 jam. Rata-rata kematian dari dosis ini sebesar 23 ekor dengan presentase kematian 93\% selama 48 jam perlakuan.

3. Kematian Larva Pada Dosis $9 \%$ Berdasarkan hasil pengamatan yang diperoleh dapat diketahui angka kematian larva nyamuk Aedes aegypti yang diberikan dengan dosis $9 \%$ memiliki angka kematian tertinggi. Pengamatan terhadap kematian larva dilakukan dalam kurun waktu 1 jam, 6 jam, 12 jam, dan 48 jam. Rata-rata kematian dari dosis ini sebesar 24 ekor dengan presentase kematian $96 \%$ selama 48 jam perlakuan.

4. Efektivitas kematian larva Pada dosis $7 \%, 8 \%$, dan $9 \%$.

Berdasarkan hasil pengamatan yang diperoleh dapat diketahui efektivitas kematian larva nyamuk Aedes aegypti yang diberikan dengan dosis $7 \%, 8 \%$, dan $9 \%$. Berdasarkan penelitian yang telah dilakukan pada ketiga dosis ini, dosis yang paling efektif untuk membunuh larva adalah dosis $7 \%$ karena telah mampu membunuh 50\% larva dari jumlah larva uji $\left(\mathrm{LD}_{50}\right)$, dan jika dilihat dari definisi efektivitas itu sendiri yaitu suatu ukuran yang menyatakan seberapa jauh target telah tercapai, dimana makin besar persentase target yang dicapai, makin tinggi efektifitasnya.

5. Perbedaan Jumlah Kematian Larva Nyamuk Aedes aegypti

Uji bio-essay (hayati) merupakan uji yang digunakan untuk memantau status kerentanan. Uji bio-essay menggunakan stadium larva maupun dewasa dari serangga uji. Persyaratan uji harus dipenuhi yaitu jumlah yang cukup serta kondisi fisiologis serangga antara lain keseragaman umur, stadium, ujuran, kondisi hidup, kenyang darah atau kenyang gula. Pengumpulan data kematian serangga uji dilakukan setelah pemaparan insektisida(7)

Uji statistik Kruskal wallis. dilakukan untuk membuktikan ada tidaknya perbedaan yang bermakna pada hasil analisis. Berdasarkan uji Kruskal wallis dengan dengan nilai sig $\mathrm{P}$ (Probabilitas) sebesar 0,04 yang artinya $\mathrm{H}_{\mathrm{o}}$ ditolak dan $\mathrm{H}_{\mathrm{a}}$ diterima, karena nilai sig $\mathrm{P}$ (Probabilitas) $<0,05$. Hasil ini menyatakan bahwa ada perbedaan yang bermakna

1 Mahasiswa Jurusan Kesehatan Lingkungan Poltekkes Denpasar

2 Dosen Jurusan Kesehatan Lingkungan Poltekkes Denpasar 
antara kematian larva terhadap masingmasing dosis uji secara siginifikan..

$$
\text { Untuk melihat adanya dua }
$$

kelompok yang memiliki perbedaan yang signifikan dilanjutkan dengan uji Mann Whitney. Pada uji ini menunjukkan bahwa hanya ada satu kelompok uji yang berbeda secara signifikan dan ada dua kelompok uji yang tidak berbeda secara signifikan.

Adapun hasil dari uji Mann Whitney antar kelompok uji tersebut yaitu, nilai $\mathrm{p}<0,05$ yaitu dosis $7 \%$ vs dosis $8 \%(\mathrm{p}=0,003)$, dan dosis $7 \%$ vs $9 \%(p=0,003)$. Nilai $p>0,05$ yaitu dosis $8 \%$ vs dosis $9 \%(p=0,127)$. Hasil ini menunjukkan adanya pengaruh pemberian perlakuan ekstrak daun kemangi terhadap larva nyamuk Aedes aegypti yang dihitung dalam kurun waktu 48 jam setelah pemberian perlakuan. Kemampuan daya bunuh ekstrak daun kemangi pada dosis 8\% dan dosis 9\% dengan presentase mencapai $93 \%$ dan 96\%., dan pada dosis $7 \%$ dengan presentase $73 \%$ kematian larva Aedes aegypti.

Daya bunuh insektisida hayati berasal dari senyawa kimia yang dikandungnya, seperti alkaloid, eugenol, saponin, flavonoid dan tannin. Senyawasenyawa ini bersifat racun perut atau racun kontak terhadap serangga. Sebagai racun perut, insektisida memasuki tubuh serangga melalui saluran pencernaan makanan, serta dinding tubuh. Disamping itu daun kemangi juga mengandung senyawa kimia yang menyebabkan gangguan pada system saraf serangga. Gangguan ini menghalangi rangsangan dari system saraf pusat ke otot sehingga dapat menimbulkan kekejangan dan lumpuh pada otot serangga. Proses inilah

\section{DAFTAR PUSTAKA}
1. Achmadi.F. Dasar-Dasar Penyakit
Berbasis Lingkungan. Jakarta: PT
Grafindo Persada; 2012.
2. Chandra.B. Ilmu Kedokteran

yang menyebabkan kematian dari serangga (8)

\section{SIMPULAN DAN SARAN}

(1) Pada dosis 7\% ekstrak daun kemangi, jumlah kematian larva nyamuk Aedes aegypti rata-rata 18 ekor dengan presentase kematian $73 \%$. (2) Pada dosis $8 \%$ ekstrak daun kemangi, jumlah kematian larva nyamuk Aedes aegypti rata-rata 23 ekor dengan presentase kematian 93\%. (3) Pada dosis 9\% ekstrak daun kemangi, jumlah kematian larva nyamuk Aedes aegypti ratarata 24 ekor dengan presentase kematian 96\%. (4) Ekstrak daun kemangi pada dosis $7 \%$ dengan $8 \%$ dan dosis $7 \%$ dengan $9 \%$ memiliki perbedaan secara signifikan, dosis $8 \%$ dengan $9 \%$ tidak signifikan. Serta ekstrak daun kemangi yang efektif dalam membunuh larva adalah dosis $7 \%$ dengan jumlah larva yang mati rata-rata 18 ekor atau $73 \%$ dari jumlah larva uji $\left(\mathrm{LD}_{50}\right)$. Adapun saran yang diberikan adalah (1) Agar masyarakat Memanfaatkan bahan bahan alami sebagai pestisida sebagai pembasmi larva nyamuk Aedes aegypti, karena penggunaan pestisida alami dalam kehidupan sehari-hari tidak menimbulkan dampak yang negatif terhadap lingkungan dan kesehatan diri sendiri. (2) Masyarakat dapat menggunakan serbuk daun kemangi sebagai pengganti ekstrak, mengingat ekstrak daun kemangi dibuat dengan menggunakan metode ilmiah. Diharapkan dalam penelitian selanjutnya pembuatan ekstrak dengan metode maserasi menggunakan waktu yang telah ditentukan sesuai dengan teori yaitu \pm 10 hari agar ekstrak yang nantinya digunakan sudah memadai.

1 Mahasiswa Jurusan Kesehatan Lingkungan Poltekkes Denpasar

2 Dosen Jurusan Kesehatan Lingkungan Poltekkes Denpasar

Pencegahan Komunitas. Jakarta: EGC; 2006.

3. Haditomo.I. Efek Larvasida Ekstrak Daun Cengkeh (Syzygium 
aromaticum L) Terhadap Aedes aegypti. Universitas Sebelas Maret Surakarta; 2010.

4. Ika Merdeka Wati D. Efektivitas Minyak Atsiri Daun Kemangi. J Nat Sci. 2015;4(1):1-9.

5. Sudarsono.dkk. Tumbuhan Obat II. Yogyakarta: Universitas Gajah Mada; 2002. 136-140 p.

6. Soegijanto.S. Demam Berdarah Dengue. Surabaya: Airlangga University Press; 2004.

7. Sucipto. Vektor Penyakit Tropis. Yogyakarta: Gosyen Publishing; 2011.

8. Fitri Nadifah., Anik Nuryati NI. Daya Larvasida Ekstrak Daun Kemangi (Ocimum Citriodorum) Terhadap Larva Nyamuk Aedes aegypti instar III. STIKES Guna Bangsa; 2014. 